International Journal of Industrial Engineering Research and Development (IJIERD)

Volume 6, Issue 2, July-Dec 2015, pp. 12-18, Article ID: IJIERD_06_02_002

Available online at https://iaeme.com/Home/issue/IJIERD?Volume $=6 \&$ Issue $=2$

ISSN Print: 0976 - 6979 and ISSN Online: 0976 - 6987

DOI: https://doi.org/10.34218/IJIERD.6.2.2015.002

(C) IAEME Publication

\title{
STUDY ON THE OCCUPATIONAL STRESSORS OF INDIAN SEAFARERS
}

\author{
Dr. J. Rengamani \\ Associate Professor, AMET Business School, AMET University, India
}

V. Venkatraman

Research Scholar, AMET University, India

\begin{abstract}
The study aims to investigate the impact of the factors of occupational stress on the job satisfaction of seafarers. The occupational stress is considered as one of the most important workplace hazards for seafarers, which may have a detrimental effect on the job satisfaction. In the competitive 24-hour industry where shift work and long working hours are common, the potential for stress at sea is extremely high. Stress is associated with impaired individual functioning in the workplace and the negative effects of the stress include reduced efficiency, decreased capacity to perform, dampened initiative and reduced interest in working, increased rigidity of thought, a lack of concern for the colleagues and a loss of responsibility (Greenberg and Baron, 1995; Matteson and Ivancevich, 1982). Stress has been associated with important occupational outcomes of job satisfaction, organisational commitment and employee withdrawal behaviour (Naumann, 1993; Sullivan and Bhagat, 1992; Tett and Meyer, 1993; Williams and Hazer, 1986). High levels of work stress are associated with low levels of job satisfaction (Landsbergis, 1988; Terry et al., 1993) and the job stressors are predictive of job dissatisfaction and a greater propensity to leave the organisation. The study had analysed the occupational stress and its impact on the job satisfaction of the seafarers' using the dimensions of Job Description Index model.
\end{abstract}

Key words: Occupational Stress, Stressors, Job Satisfaction, Job Description Index (JDI).

Cite this Article: Dr. J. Rengamani and V. Venkatraman. Study on The Occupational Stressors of Indian Seafarers, International Journal of Industrial Engineering Research and Development, 6(2), 2015, pp. 12-18.

http:// http://www.iaeme.com/issue.asp?JType=IJIERD\&VType=6\&IType $=2$ 


\section{INTRODUCTION}

The Job Stress is a common problem for all the transportation modes and industries. The effects of stress at sea are particularly dangerous due to the specialized nature of seafaring, which requires constant alertness and intense concentration from its seamen. Furthermore, the long periods away from home, limited communication among colleagues and consistently high workloads, separate seafaring profession from other industries. Working in these circumstances, the seafarers' health, even their life-span, may be affected by extreme stress and impaired performance (Smith, 2007).

The experience of stress reactions in the workplace is not an isolated phenomenon (Fletcher, 1988). A number of aspects of working life have been linked to stress and the different aspects of the work itself can be stressful, namely work overload (DeFrank and Ivancevich, 1998; Sparks and Cooper, 1999, Taylor et al., 1997) and role-based factors such as lack of power, role ambiguity, and role conflict (Burke, 1988; Nelson and Burke, 2000). The quality of the social environment in the workplace is associated with stress (Sparks and Cooper, 1999) as are certain behaviours of the leader (Carlopio et al., 1997; Cooper and Marshall, 1976). Threats to career development and achievement, including threat of redundancy, being undervalued and unclear promotion prospects are stressful (Nelson and Burke, 2000). The conflict between home and work and the work impact on personal relationships is stressful (Sparks and Cooper, 1999). Also, physical conditions such as high noise levels, overcrowding in the workplace or a lack of privacy have been associated with stress.

Furthermore, occupational stress creates to be endemic to the current workplace and there are a number of workplace factors, called Stressors that make jobs stressful and difficult for number of employees in all sorts of industries. Additional stressors related to interpersonal relationships at work are conflicts with supervisors, conflicts with colleagues, conflicts with subordinates and conflicts with management policies (Paul Spector, 2002). Kahn and Byosiere, (1992), Taylor, (1999) and Paul (2002) further pointed out that there are some other stressors in the organizational context, such as having insufficient resources to do the job (e.g., defective equipment or inadequate supplies), or low salaries structure. Research has clearly demonstrated that all of these stressors are connected with employees' health and well-being. As is characteristically found in various studies, higher levels of stressors (e.g., heavy workload and uncertainty about supervisors' expectations) were associated with physical symptoms, such as headaches, and poor job attitudes.

Job satisfaction is central to the work lives of seafarers' and to the effective use of personnel within organisations (Foster 2000, Koeske et al 1994). When satisfied at work, seafarers' are likely to be more stable, productive and accomplished towards organisational goals. According to research, human service workers who derive satisfaction from their work are more committed and provide better services, than those who are dissatisfied (Acker 1999). Job satisfaction involves employees' affective or emotional feelings, it has major consequences on their lives. Locke (1976) described the most common consequences of job satisfaction on employees as, the effects on the physical health and longevity; mental health and an impact on the employees' social life in general.

Several stress theories differ in their views of the major determinants of stress; some theories put emphasis on personal characteristics of human being (e.g., Friedman \&Rosenman, 1974; Kobasa, 1979); others highlight that stress is the cause 
of work environment (e.g., Siegrist, 1996; Edwards, Caplan, \& Van Harrison, 1998; Demerouti, Bakker, \&Schaufeli, 2001) and some view stress as a function of an interaction between person (worker) and environment (workplace). The Job Description Index (JDI) was developed by Smith, Kendall and Hulin in 1969 and is the most widely used instrument measuring employees' job satisfaction within organisations (Kreitner\&Kinicki, 1995). Spector (2000) adds that the JDI is directed towards specific areas of satisfaction rather than merely global satisfaction and allows for different areas of the job to be independently measured.

\section{RESEARCH OBJECTIVES}

The objectives of the study were to analyze the impact of stress factors on the job satisfaction of the seafarers:

- To investigate the relationship between the facets of Work role, Disruption of everyday routine, Ship's environment, Disruption of Social life, Teamwork, Physical environment and the Job satisfaction of seafarers.

- To study the relationship between the facets of Job Descriptive Indices and the Job satisfaction of seafarers.

In order to achieve the objectives, this article is organized around the following working hypotheses:

- $\mathrm{H}_{1}$ : There is a significant relationship between the scores of stressors \& job satisfaction.

- $\mathrm{H}_{2}$ : There is a significant relationship between the nature of the job, pay, supervision, promotion, and co-workers with job satisfaction amongst seafarers.

\section{RESEARCH METHODOLOGY}

The target population was considered as seafarers of Indian origin who were working at various levels/job categories on the deck side (Master, Chief officer, $2^{\text {nd }} / 3^{\text {rd }}$ officer, Bosun) and the engine side (Chief Engineer, $2^{\text {nd }} / 3^{\text {rd }} / 4^{\text {th }}$ Engineer) of foreign going merchant vessels. The total sample size considered for the study was 385, which is arrived by using the sampling formula suggested by Cochran (1963) with $95 \%$ confidence level and $\pm 5 \%$ precision. The sample responses were obtained by using quota sampling.

The study consists of two parts. In the first part of the study, a questionnaire was administered by specifying the dimensions of stressors \& Job satisfaction such as Work role (Work expectations, Fair work assessment, Responsibility to carry-out the work), Disruption of everyday routine (Missed meals, Less exercise), Ship climate (High morale, No fear while on-board, Assisting peers), Disruption of Social life (Separation from family, No socialization), Teamwork (Group activities, Conflict with peers), Physical environment (Climatic conditions, Uncomfortable rest place), Job satisfaction (Payment, Appropriate rest, Working hours), were measured on a fivepoint likert scale.

In the second part of the study, Job Descriptive Index questionnaire (JDI) was administered to gather the data from the seafarers. JDI questionnaire requires the seafarers to describe their work as opposed to directly asking seafarers how satisfied they are, thereby ensuring that respondents have a job referent rather than a selfreferent. The JDI measures satisfaction perceptions for five Job facets, namely: Pay, Promotions, Supervision, Co-workers and the Work itself (Spector, 2000). The 
research instrument consists of 32 items - Nature of the Job facet comprises of 7 items such as "Routine, Hot (temperature), Tiresome, Challenging, On your feet, Frustrating, Gives a sense of accomplishment"; Pay facet comprises of 5 items such as "Adequate Income, Income provides luxuries, Insecure, Less than I deserve, Underpaid"; Supervision facet comprises of 8 items such as "Asks my advice, Impolite, Praises good work, Doesn't supervise enough, Quick tempered, Knows job well, Leaves me on my own, Lazy"; Promotion facet comprises of 6 items such as "Good opportunities for advancement, Opportunities somewhat limited, Promotion on ability, Good chance for promotion, Unfair promotion policy, Regular promotions"; Co-workers facet comprises of 6 items such as "Stimulating, Slow, Ambitious, Responsible, Talk too much, Lazy". To score the responses, seafarers are requested to indicate whether each item does or does not describe their jobs, by using a 3-point scale.

\section{STATISTICAL ANALYSIS}

In the first part of the study, the internal consistency and reliability of the scales were tested by computing the cronbach's alpha values. The scales of the factors such as Work role, Disruption of everyday routine, Ship climate, Disruption of Social life, Teamwork, Physical environment \& Job satisfaction have good internal consistency $\&$ reliability with the alpha values of $0.89,0.91,0.82,0.84,0.92,0.88$ and 0.91 respectively.

Table 1 Cronbach's Alpha Values

\begin{tabular}{|l|l|}
\hline Factors & $\begin{array}{l}\text { Cronbach's } \\
\text { Alpha }\end{array}$ \\
\hline & \\
\hline & 0.91 \\
\hline Ship climate & 0.82 \\
\hline Disruption of Social life & 0.84 \\
\hline Teamwork & 0.92 \\
\hline Physical environment & 0.88 \\
\hline Job satisfaction & 0.91 \\
\hline
\end{tabular}

The Pearson's Product Moment Correlation Coefficients were calculated between the stressors and job satisfaction. The results (Table-2) showed a significant relationship (all $\mathrm{r}$ values were greater than +0.71 and all the corresponding $\mathrm{p}$-values were less than 0.05 ) between stressors and job satisfaction. The correlation analysis indicates that the factors of stress considered in the study and the job satisfaction of the seafarers are statistically significant. Any modification of the factors (such as the work role, physical environment, everyday routine \& ship's climate) in the adverse manner may definitely put the seafarer under stressful condition and ultimately the seafarer may become dissatisfied with the job.

In the second part of the study, the JDI facets such as Job, Pay, Supervision, Promotion and Co-workers have good internal consistency \& reliability with the Cronbach's alpha values of $0.72,0.84,0.76,0.89$ and 0.77 respectively. 
Study on The Occupational Stressors of Indian Seafarers

Table 2 Pearson's Product Moment Correlation Coefficients

\begin{tabular}{|l|l|l|}
\hline \multirow{2}{*}{ Stressors } & \multicolumn{2}{|c|}{} \\
\cline { 2 - 3 } & $\mathrm{R}$ values & $\mathrm{p}$ values \\
\hline Work role & 0.75 & 0.032 \\
\hline Disruption of everyday routine & 0.83 & 0.021 \\
\hline Ship climate & 0.72 & 0.028 \\
\hline Disruption of Social life & 0.96 & 0.012 \\
\hline Teamwork & 0.88 & 0.026 \\
\hline Physical environment & 0.94 & 0.014 \\
\hline
\end{tabular}

Table 3 Cronbach's Alpha Values of JDI facets

\begin{tabular}{|l|l|}
\hline JDI Factors & $\begin{array}{l}\text { Cronbach's } \\
\text { Alpha }\end{array}$ \\
\hline Job & 0.72 \\
\hline Pay & 0.84 \\
\hline Supervision & 0.76 \\
\hline Promotion & 0.89 \\
\hline Co-workers & 0.77 \\
\hline Job Satisfaction & 0.78 \\
\hline
\end{tabular}

The Pearson's Product Moment Correlation Coefficients were calculated between the JDI facets and job satisfaction. The results (Table-4) showed a significant relationship (all $\mathrm{r}$ values were greater than +0.69 and all the corresponding $\mathrm{p}$-values were less than 0.05) between the JDI facets and job satisfaction. Based on the analysis, it may therefore be specified that the job satisfaction depends on the JDI facets such as nature of the job, pay, supervision, promotion and co-workers cooperation.

Table 4 Pearson's Product Moment Correlation Coefficients

\begin{tabular}{|l|l|l|}
\hline \multirow{2}{*}{ JDI Factors } & \multicolumn{2}{|c|}{} \\
\cline { 2 - 3 } Job & R values & $\mathrm{p}$ values \\
\hline Pay & 0.95 & 0.011 \\
\hline Supervision & 0.89 & 0.021 \\
\hline Promotion & 0.70 & 0.028 \\
\hline Co-workers & 0.94 & 0.012 \\
\hline
\end{tabular}

\section{CONCLUSION}

Seafarers' stress has become a global concern across the shipping industry. Stress is a complicated issue which is caused and affected by many factors. In light of these indications, a comprehensive identification of stressors was made through seafarers.

Seafarers under excessive stress tend to find their jobs less satisfying. Some of their intrinsic or extrinsic needs may be thwarted or not met sufficiently. It was found that a clear relationship existed between the facets of stress and job satisfaction. The subjects with lower job satisfaction were found to experience more stress in the form of overload, role ambiguity, role conflict, under participation, powerlessness and low 
status compared to those with higher job satisfaction. Furthermore, Stress was experienced due to loss of control over obtaining desired outcomes on the job.

Emphasising the role of individual differences in relation to stress in the workplace could present the temptation to see stress as a personal weakness or failing not as a systematic problem of job design. The personality traits of external locus of control and behaviours are associated with higher perceived levels of stress originating from work place dimensions. Internal locus of control linked to better psychological health and a lower level of occupational stress, and greater job satisfaction.

Stress was consistently associated with poor sleep quality, negative environmental factors, high job demands and high stress. In addition, those on shorter tours of duty were consistently more likely to report high stress levels. Other factors found to be important included: frequent port visits, physical work hazards, working more than 12 hours a day, low job support and finding the switch to port work stressful. The additive combination of different risk factors proved most highly associated with stress and with its immediate consequences as job dissatisfaction.

The empirical findings from the study indicate that the factors such as pay, the nature of job, supervision, relationships with co-workers and opportunities for promotions have been found to contribute to job satisfaction of seafarers. Stress can impair the seafarers' performance at work, diminish their alertness, and affect their problem-solving and decision-making abilities.

\section{REFERENCES}

[1] Allen, C. (2003). Psychology today: Rank determines job satisfaction.

[2] J.T. Barnowe, "Leadership and performance outcomes in research organizations: The supervisor of scientists as a source of assistance", Organizational Behavior and Human Performance, Volume 14, Issue 2, 1975, Pages 264-280, https:// doi.org/10.1016/0030-5073(75)90029-X

[3] Bradley G (2004). "A Test of Demands-Control - Support Model. Job Strain and healthy work". School of Applied Psychology. Griffith University, Australia. https://doi.org/10.25904/1912/2305

[4] Brown, I.D. (1989). Study into hours of work, fatigue and safety at sea. Medical Research Council: Cambridge.

[5] Caplan R, Cobb S, French J, Van Harrison R, Pinneau S (1975). Job demands and worker health. Washington D. C.: Institute for Social Research, University of Michigan/ National Institute of Occupational Safety and Health.

[6] Collins, A., Mathews, V., and McNamara, R. (2000). Fatigue, health and injury among seafarers \& workers on offshore installations: A review. Cardiff University Seafarers International Research Centre/Centre for Occupational \& Health Psychology.

[7] Cook JD, Hepworth SJ, Warr TD, Warr PB (1981). The experience of work: London Academic Press.

[8] Cronbach LJ (1951). Coefficient alpha and the internal structure of tests. Psychometrika, 16, 297-334 (1951). https://doi.org/10.1007/BF02310555

[9] Feather, N.T., \& Rauter, K.A. (2004). Organizational citizenship behaviours in relation to job status, job insecurity, organizational commitment and identification, job satisfaction and work values. Journal of Occupational $\begin{array}{llll}\text { and Organizational Psychology. } & \text { 77(1), } & \text { pp. } & \text { 81-94 }\end{array}$ https://doi.org/10.1348/096317904322915928 
[10] Folkard, S., Lombardi, DA and Tucker, PT. (2005). Shiftwork: safety, sleepiness and sleep. Industrial Health.

[11] French, J. R. P., Jr., Caplan, R. D., and Harrison, R. V. 1982. Mechanisms of Job Stress and Strain. New York: John Wiley \& Sons.

[12] Gloria Jones Johnson \& W. Roy Johnson (2000) Perceived Overqualification and Dimensions of Job Satisfaction: A Longitudinal Analysis, The Journal of Psychology, 134:5, 537-555, DOI: 10.1080/00223980009598235

[13] Karasek R, Triantis K, Chaudhry SS (1982). "Co-worker and supervisor support as moderators of associations between task characteristics and mental strain". Journal of Organizational Behavior, 3(2), pp. 181-200.

[14] Meyer, M. (1999). Managing human resources development - An outcomesbased approach. Durban: Butterworth Publishers (Pty) Ltd.

[15] Robie, C., Ryan, A. M., Schmieder, R. A., Parra, L. F., \& Smith, P. C. (1998). The Relation between Job Level and Job Satisfaction. Group \& Organization Management, 23(4), 470-495. https://doi.org/10.1177/1059601198234007

[16] Viswesvaran, C., Deshpande, S.P. \& Joseph, J. Job Satisfaction as a Function of Top Management Support for Ethical Behavior: A Study of Indian Managers. Journal of Business Ethics 17, 365-371 (1998). https://doi.org/10.1023/A:1017956516324 